\title{
ANALISIS PERBANDINGAN FIKSASI MENGGUNAKAN LARUTAN FORMALIN DAN LARUTAN CARNOY PADA SOMIT, NEURAL TUBE, DAN VASKULAR EMBRIO AYAM USIA 48 JAM DENGAN PEWARNAAN HEMATOXYLIN-EOSIN
}

\author{
Ernst Randy Nuralim, Indriati Dwi Rahayu ${ }^{* \star 凶}$, Rachmad Sarwo Bekti ${ }^{\star \star *}$
}

\begin{abstract}
Abstrak
Penelitian embriologi memiliki peran penting dalam dunia kesehatan, oleh karena itu diperlukan pengetahuan berbagai faktor pendukung salah satunya adalah larutan fiksatif. Meskipun telah diketahui bahwa larutan Carnoy memberikan efek pengerutan hingga dapat menghancurkan sitoplasma, banyak penelitian yang menggunakan larutan Carnoy sebagai pilihan utama untuk larutan fiksatif pada penelitian embrio ayam. Penelitian ini bertujuan untuk menguji kualitas gambaran embrio yang difiksasi menggunakan larutan Carnoy dan membandingkannya dengan kualitas gambaran embrio yang difiksasi menggunakan larutan formalin. Telur ayam yang digunakan diperoleh dari peternakan ayam Randu Agung Singosari. Telur ayam diinkubasi selama 48 jam, lalu satu kelompok difiksasi menggunakan larutan Carnoy dan kelompok yang lain difiksasi menggunakan larutan formalin. Hasil fiksasi kemudian dibuat preparat dan diwarnai dengan pewarnaan hematoxylin-eosin (HE), untuk selanjutnya dilakukan evaluasi terhadap somit, vaskuler, dan neural tube. Hasil penelitian dianalisis menggunakan paired $T$ test menunjukkan bahwa larutan Carnoy memberikan hasil yang signifikan berbeda $(p<0,05)$ dengan larutan formalin pada evaluasi somit dan vaskuler embrio ayam usia 48 jam, namun memberikan hasil yang signifikan tidak berbeda $(p>0,05)$ penggunaan larutan Carnoy dengan larutan formalin pada evaluasi neural tube embrio ayam usia 48 jam. Kesimpulan dari penelitian ini adalah fiksasi dengan larutan formalin menunjukkan hasil yang berbeda dengan fiksasi menggunakan larutan Carnoy pada evaluasi somit dan vaskuler, namun tidak berbeda pada evaluasi neural tube embrio ayam usia 48 jam.
\end{abstract}

Kata kunci: embrio, hematoxylin-eosin, larutan Carnoy, larutan formalin, somit, neural tube, vaskular.

\section{COMPARATIVE ANALYSIS OF FIXATION USING CARNOY SOLUTION AND FORMALIN SOLUTION IN CHICKEN EMBRYO'S SOMITES, NEURAL TUBE, AND VASCULAR AGE OF 48 HOURS WITH HEMATOXYLIN-EOSIN STAINING}

\begin{abstract}
Embryology research has an important role in health, therefore need to know variety of supporting factors such as fixative solutio.. It has been known that Carnoy solution's have the shrinkage effect to cytoplasm, but many research still used Carnoy solution as a fixative solution to study the chicken embryo. This study was aimed to examine the image quality of chicken embryo that is fixed using Carnoy solution compared to formalin solution. Fertilized chicken eggs used were obtained from chicken farms at Randu Agung Singosari. Fertilized chicken eggs were incubated for 48 hours, and then one group were fixed using Carnoy solution and the other group were fixed in a formalin solution. After fixation process, the slides were stained with hematoxylin-eosin (HE) method and evaluated the somit, vascular and neural tube of the embryo. The comparative analysis using paired T test showed that Carnoy solution were significantly different $(p<0.05)$ with formalin to evaluate the chick embryo somites and vascular age of 48 hours. The results also showed that Carnoy solution were not significantly different $(p>0.05)$ with formalin to evaluate the neural tube of chick embryos at age of 48 hours. As the conclusion, the fixation using Carnoy solution and formalin is significantly different in evaluating somites and vascular, but is not different significantly in evaluating neural tube on 48 hours age of chick embryo.
\end{abstract}

Keywords: Carnoy solution, embryo, formalin solution, hematoxylin-eosin, somite, neural tube, vascular.

\footnotetext{
* Program Studi Pendidikan Dokter, FKUB

** Lab Anatomi dan Histologi, FKUB

*** Lab Patologi Anatomi, FKUB
}

凶indri.fkub@gmail.com 


\section{Pendahuluan}

Embriologi merupakan ilmu yang mempelajari tentang perkembangan embrio sejak dari masa pembuahan telur sampai dengan pembentukan janin. ${ }^{1}$ Penelitian dalam bidang ini sangat penting untuk mencegah terjadinya kegagalan perkembangan embrio yang pada akhirnya dapat menyebabkan kecacatan atau bahkan kematian pada janin. Oleh karena itu, diperlukan metode, sampel, serta bahan fiksatif yang dapat memberikan gambaran perkembangan embrio yang serupa dengan perkembangan embrio pada manusia. Dalam penelitian ini penulis menggunakan embrio ayam sebagai sampel dan beberapa bahan fiksatif, yaitu larutan Carnoy dan larutan formalin.

Embrio ayam merupakan model yang cocok untuk memberikan gambaran perkembangan biologi, penelitian embriologi, serta teratologi. Perkembangan embrio ayam secara umum memiliki pola perkembangan dan fungsi yang identik dengan perkembangan embrio manusia. ${ }^{2}$ Di samping itu, penggunaan embrio ayam sebagai sampel dalam penelitian perkembangan embrio dan teratologi memiliki keuntungan yaitu peneliti dapat membuka telur, memeriksa embrio, dan memberikan pemaparan yang tepat pada tahap perkembangan yang spesifik, sehingga embrio ayam menjadi pilihan utama untuk diaplikasikan dalam penelitian embriologi.

Dalam pembuatan sediaan histologi yang baik diperlukan berbagai macam tahapan yang salah satunya adalah tahap fiksasi. Tahapan fiksasi merupakan tahapan yang paling penting dalam membuat sediaan histologi, karena jika terjadi kesalahan pada tahap ini akan memberikan gambaran yang buruk yang buruk pada sediaan histologi. ${ }^{3}$

Selama ini, penelitian pada embrio ayam telah banyak dilakukan dengan menggunakan bahan fiksatif larutan Carnoy.
Hal ini disebabkan karena larutan Carnoy memiliki daya penetrasi yang cepat, akan tetapi memiliki efek pengerutan yang kuat sehingga menghancurkan sitoplasma dan berakibat pada penurunan kualitas gambaran sediaan histologi. Selain itu, harga larutan carnoy cukup mahal serta sulit untuk didapatkan sehingga membatasi penggunaan larutan Carnoy dalam jumlah besar. $^{3}$ Di samping itu, proses fiksasi yang memakan waktu, prosedur yang kompleks, serta golden periode untuk pengecatan yang sempit menyebabkan kemungkinan kerusakan sediaan histologi lebih besar. Larutan formalin telah menjadi bahan fiksatif yang paling sering digunakan dan mudah untuk mendapatkannya. Dengan prosedur yang sederhana serta golden periode yang lebih panjang membuat fiksasi menggunakan larutan formalin memiliki kemungkinan kerusakan histologi lebih kecil. Penelitian ini bertujuan untuk membuktikan bahwa larutan formalin dapat digunakan sebagai pengganti larutan Carnoy dalam memfiksasi embrio ayam.

\section{Bahan dan Metode}

\section{Desain Penelitan}

Penelitian ini berjenis eksperimental dengan menggunakan rancangan purposive sampling untuk membandingkan hasil fiksasi menggunakan larutan Carnoy dan larutan formalin. Hewan coba yang digunakan adalah ayam fase embrio dalam telur ayam. Embrio ayam pada telur ayam yang telah dibuahi, diperoleh dari perusahaan pembibitan ayam PT Randu Agung Jaya, Kabupaten Malang. Spesies ayam adalah Gallus gallus strain Cobb. Tahap perkembangan embrio ayam mengikuti tabel Hamburger dan Hamilton. Telur diinkubasi pada suhu 100-102 of dengan kelembaban relatif $60-70 \%$ selama 48 jam. 


\section{Pengambilan dan Fiksasi Bahan Coba}

Pecahkan cangkang telur dengan mengetukkan dasar telur pada bidang yang agak tajam, dengan tidak merubah posisi telur. Tuang telur dalam mangkuk plastik yang telah setengahnya diisi dengan Larutan $\mathrm{NaCl}$ 0,9\% (NS). Letakkan bingkai kertas saring di atas blastodisk (embrio) sehingga nampak perlahan-lahan menjadi basah. Kemudian gunting vitelinne membrane di sisi luar bingkai kertas. Angkat bingkai kertas saring, sehingga embrio ikut menempel/berada dalam lubang pada bingkai kertas saring. Masukkan ke dalam larutan NS yang lain dan goyang-goyangkan beberapa kali. Kemudian pindahkan lagi dalam larutan NS yang lain dan goyanggoyangkan beberapa kali. Setelah itu, masukkan dalam larutan Carnoy atau larutan formalin.

\section{Pewarnaan Hematoxylin-Eosin}

Setelah proses fiksasi, embrio ayam diangkat dan dibuat irisan pada object glass, kemudian dikeringkan.Tahap pewarnaan $\mathrm{HE}$ yaitu akuades diteteskan pada object glass menggunakan pipet sebanyak 3 tetes lalu dikeringkan. Kemudian hematoxylin sebanyak 3 tetes, tunggu 10 menit, dibilas dengan air. Object glass dicelupkan dalam larutan alkohol asam sebanyak 1 kali, kemudian bilas dengan air. Object glass dicelupkan dalam larutan litium karbonat sebanyak 1 kali, kemudian bilas dengan air. Pada object glass diteteskan eosin sebanyak 5 tetes, tunggu 3 menit kemudian buang sisa eosin pada object glass. Object glass dicelupkan dalam larutan alkohol $96 \%$ sebanyak 3 kali. Object glass dicelupkan dalam larutan xylol sebanyak 3 kali. Object glass ditutup dengan cover glass. Kemudian preparat dapat dievaluasi di bawah mikroskop dengan mengamati morfologi embrio ayam usia 48 jam (somit, vaskuler, dan neural tube).

\section{Hasil}

\section{Perbandingan Fiksasi pada Somit Embrio}

Berdasarkan hasil yang diperoleh, pengambilan data menggunakan metode Likert scale dengan menilai somit (kejelasan batas dan kemampuan hitung) embrio ayam usia 48 jam, didapatkan hasil rata-rata larutan formalin $6 \pm 1,03$ dan larutan Carnoy $3,12 \pm 0,68$. Selanjutnya, dengan interrater reliability (kappa), didapatkan nilai kappa 0,43 yang menurut Landis dan Koch (1977) memiliki interpretasi moderate agreement. ${ }^{4}$ Analisis menggunakan paired $T$ test diketahui bahwa fiksasi menggunakan larutan formalin dan larutan Carnoy pada evaluasi terhadap somit embrio adalah berbeda signifikan $(p<$ 0,000). Pada Gambar 1, ditampilkan perbandingan somit embrio ayam usia 48 jam yang difiksasi menggunakan larutan Carnoy dan formalin. 

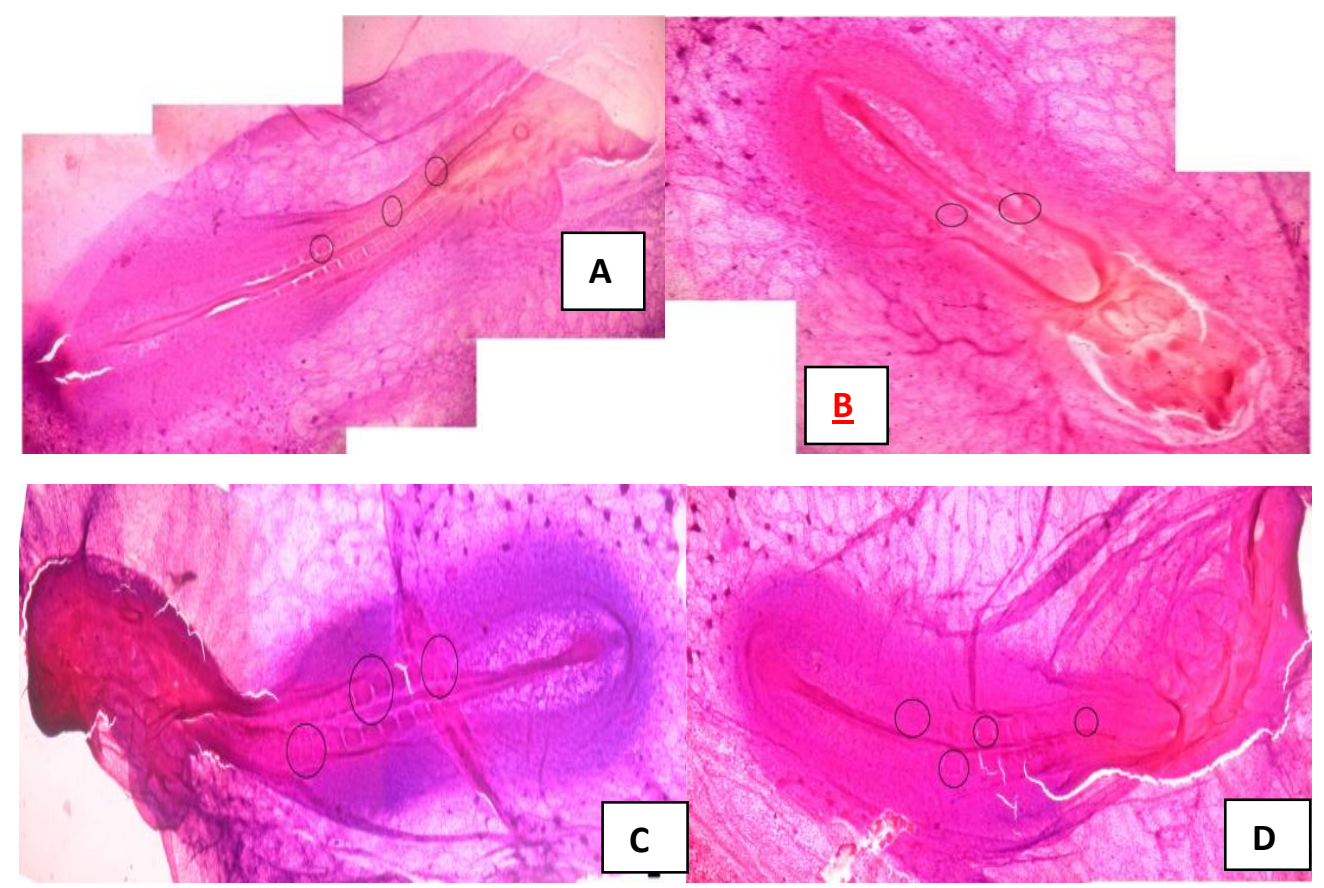

Gambar 1. Somit embrio ayam usia 48 jam (tanda lingkaran) yang difiksasi dengan larutan formalin $(A, B)$ dan larutan Carnoy (C, D) dengan pewarnaan HE.

\section{Perbandingan Fiksasi pada Neural Tube} Embrio

Berdasarkan penelitian yang telah dilakukan, pengambilan data menggunakan metode Likert scale dengan menilai neural tube (kejelasan batas) embrio ayam usia 48 jam, didapatkan hasil rata-rata larutan formalin 5,78 $\pm 0,32$ dan larutan Carnoy $5,98 \pm 0,17$. Analisis interrater reliability (kappa) didapatkan nilai kappa 0,32 yang menurut Landis dan Koch (1977) memiliki interpretasi moderate agreement. ${ }^{4}$ Selanjutnya, dilakukan uji paired $T$ test, didapatkan hasil $p=0,054$, sehingga diinterpretasikan bahwa fiksasi menggunakan larutan formalin dan larutan Carnoy pada pemeriksaan neural tube embrio tidak berbeda signifikan (lihat Gambar 2). 

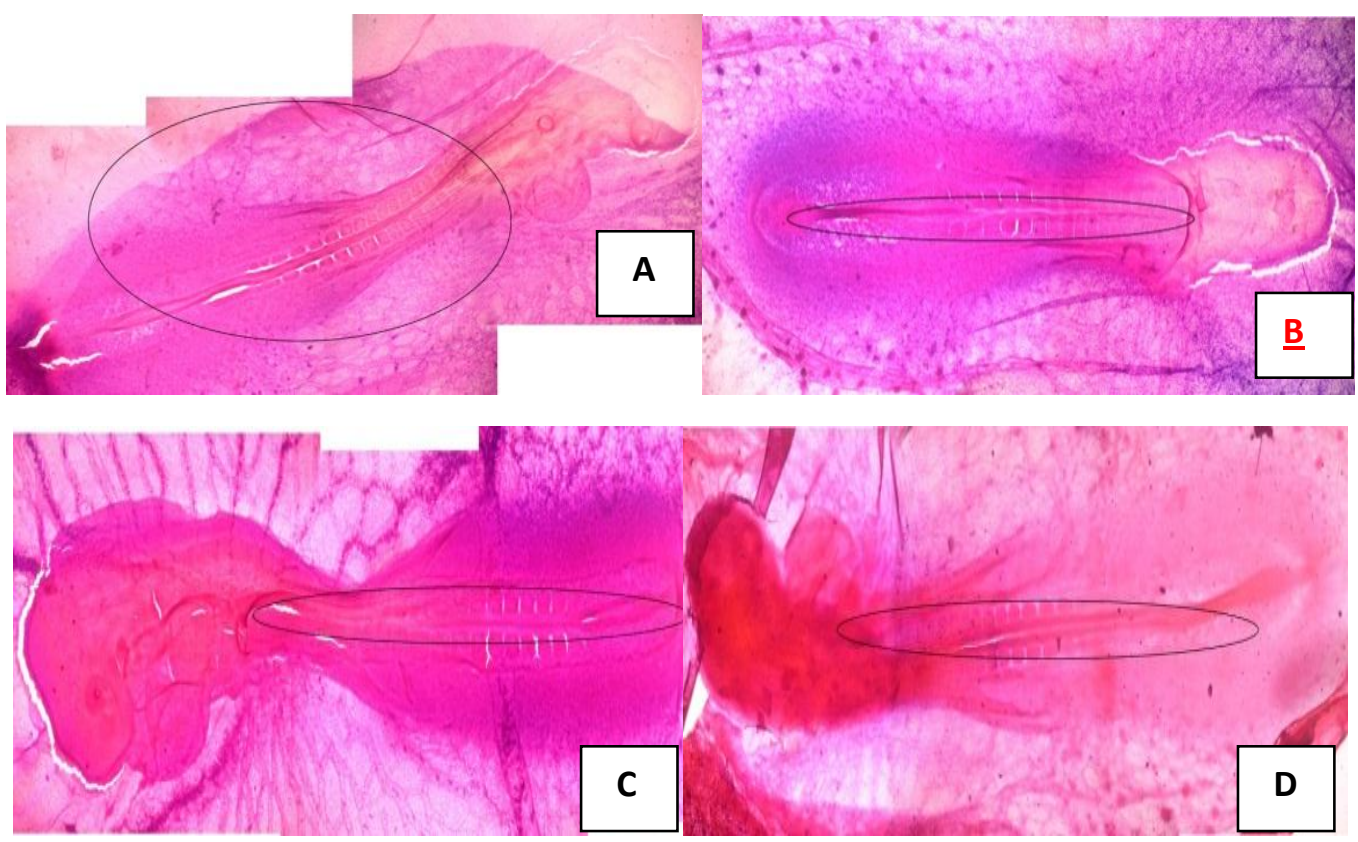

Gambar 2. Neural tube embrio ayam usia 48 jam (tanda lingkaran) yang difiksasi dengan larutan formalin $(A, B)$ dan larutan Carnoy $(C, D)$ dengan pewarnaan $H E$.

\section{Perbandingan Fiksasi pada Vaskular} Embrio

Berdasarkan penelitian yang telah dilakukan, pengambilan data menggunakan metode Likert scale dengan menilai neural tube (kejelasan batas) embrio ayam usia 48 jam, didapatkan hasil rata-rata larutan formalin 4,6 $\pm 0,41$ dan larutan Carnoy $6,27 \pm 0,59$. Kemudian penulis menggunakan interrater reliability (kappa), dan didapatkan nilai kappa 0,33yang menurut Landis dan Koch (1977) memiliki interpretasi moderate agreement. ${ }^{4}$
Selanjutnya data tersebut dianalisis menggunakan paired $T$ test, dan didapatkan hasil $p=0,00 \quad(<0,05)$, sehingga diinterpretasikan bahwa fiksasi menggunakan larutan formalin dan larutan Carnoy pada pewarnaan neural tube embrio menunjukkan perbedaan hasil secara signifikan (lihat Gambar 3). 

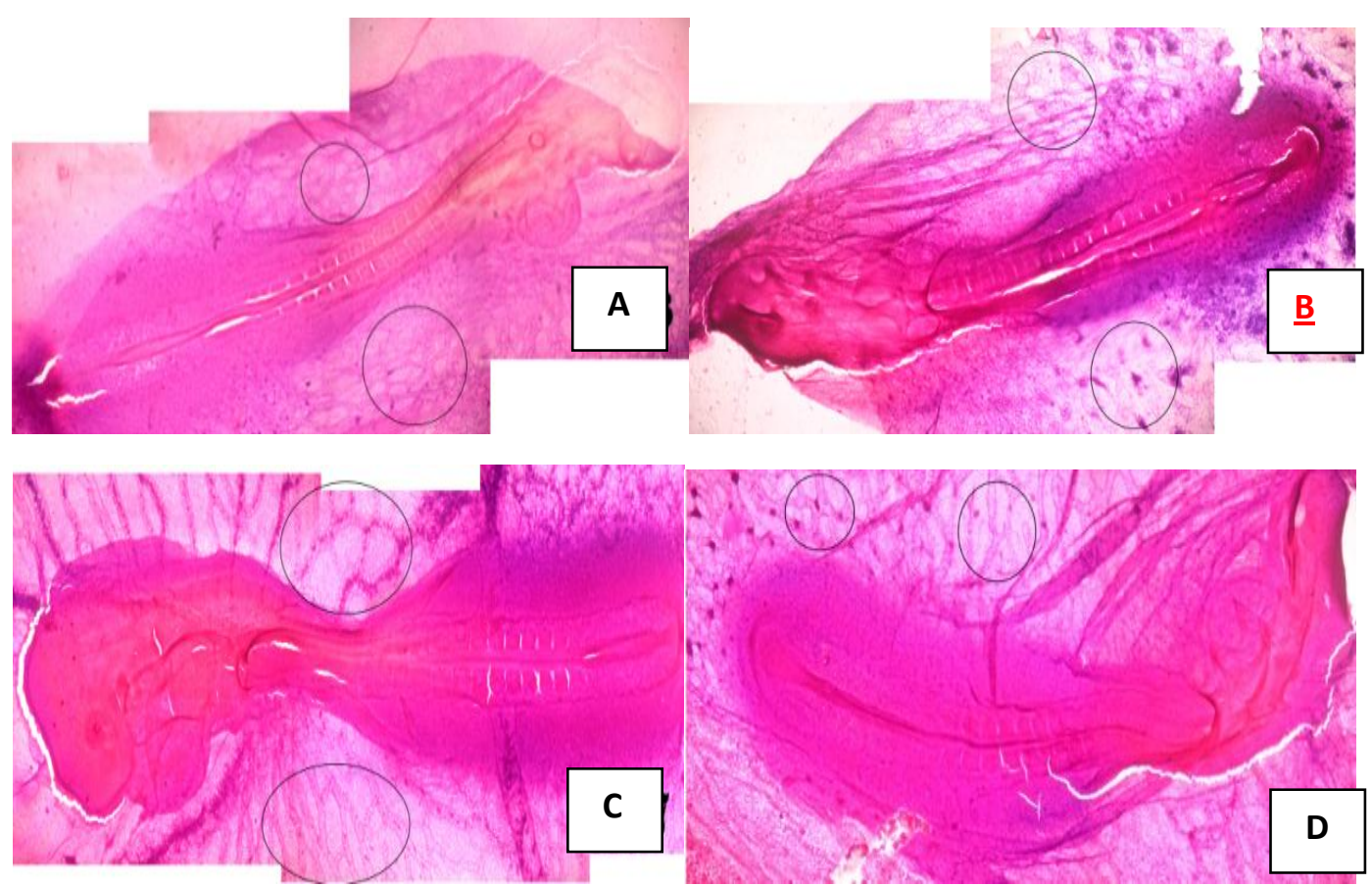

Gambar 3. Vaskular embrio ayam usia 48 jam (tanda lingkaran) yang difiksasi dengan larutan formalin $(A, B)$ dan larutan Carnoy $(C, D)$ dengan pewarnaan $\mathrm{HE}$.

\section{Pembahasan}

\section{Perbandingan Kualitas Penampakan Somit pada Bahan Fiksatif Formalin dan Larutan Carnoy \\ Dari hasil penilaian dengan} menggunakan metode Likert scale antara bahan fiksatif formalin dan larutan Carnoy diketahui kualitas penampakan dari somit lebih baik pada bahan fiksatif formalin $(6>$ $3,12)$. Pada analisis lanjutan menggunakan paired $T$ test, didapatkan nilai signifikansi $(p$ $<0,05)$ yang menunjukkan bahwa hasil perhitungan yang didapat berbeda secara signifikan. Hal ini menunjukkan bahwa bahan fiksatif formalin memberikan penampakan somit yang lebih baik jika dibandingkan dengan larutan Carnoy. Penampakan somit pada bahan fiksatif larutan Carnoy yang kurang optimal dapat disebabkan oleh beberapa faktor. Larutan Carnoy merupakan bahan fiksatif yang sebagian besar terdiri dari alkohol. Sifat denaturasi alkohol dalam preservasi jaringan dapat menyebabkan efek shrinking yang menyebabkan kerusakan jaringan akibat bentukan yang mengkerut.
Kerusakan jaringan yang didasari oleh efek denaturasi juga diikuti oleh kerusakan sitoplasma yang menyebabkan tampak sediaan menjadi buram. Selain itu, bahan fiksatif yang mengandung alkohol seperti larutan Carnoy yang memiliki kemampuan instant coagulant, terkadang dapat menyebabkan kerusakan pada mikro anatomi hewan seperti embrio yang pada penelitian ini didapatkan hasil yang serupa yaitu berupa gambaran somit yang tidak jelas dan hilangnya bentukan somit pada embrio. ${ }^{5}$ Hal ini berbeda pada gambaran bahan fiksatif formalin, selain struktur somit yang dapat terevaluasi dan terhitung dengan jelas jarang terdapat bentukan, serta menghindarkan otolisis jaringan yang dapat terjadi akibat perlakuan fiksasi. Hal ini menunjukkan bahwa pada penelitian yang menekankan pada kualitas penampakan somit embrio, bahan fiksatif pilihan yang digunakan adalah formalin. 


\section{Perbandingan Kualitas Penampakan Neural Tube pada Bahan Fiksatif Formalin dan Larutan Carnoy \\ Dari hasil penilaian dengan} menggunakan metode Likert scale antara bahan fiksatif formalin dan larutan Carnoy diketahui kualitas penampakan dari neural tube tidak jauh berbeda pada bahan fiksatif formalin $(5,78: 5,98)$. Pada analisis lanjutan menggunakan paired $T$ test, didapatkan nilai yang tidak signifikan berbeda $(p>0,05)$ yang menunjukkan bahwa hasil perhitungan yang didapat tidak berbeda secara signifikan. Hal tersebut kemungkinan didasari oleh bentukan neural tube yang merupakan sebuah canal, sehingga kerusakan sitoplasma pada bahan fiksatif larutan Carnoy yang menyebabkan pewarnaan yang diffuse tidak terlalu mempengaruhi penampakan neural tube dan masih dapat terevaluasi dengan baik. ${ }^{6}$

\section{Perbandingan Kualitas Penampakan Vaskularisasi pada Bahan Fiksatif Formalin dan Larutan Carnoy \\ Dari hasil penilaian dengan} menggunakan metode Likert scale antara bahan fiksatif formalin dan larutan Carnoy diketahui kualitas penampakan dari vaskularisasi berbeda pada bahan fiksatif formalin $(6,27>4,6)$. Pada analisis lanjutan menggunakan paired $T$ test, didapatkan nilai yang signifikan $(p<0,05)$ yang menunjukkan bahwa hasil perhitungan yang didapat tidak berbeda secara signifikan. Pada penelitian ini, bentukan struktur antara jaringan dengan bahan fiksatif formalin dan larutan Carnoy memiliki perbedaan gambaran yang signifikan. Perbedaan utama kualitas yang jelas terdapat pada vaskular yang terwarnai oleh pengecatan hematoxyilin-eosin. Pada fiksasi larutan formalin, vaskular terwarnai dengan baik tetapi jika dibandingkan dengan vaskular yang difiksasi dengan larutan Carnoy, perbedaaan warna vaskuler dengan lingkungan lebih terlihat jelas. Sehingga batas-batas vaskular terlihat lebih jelas dan memudahkan dalam mengevalusi perkembangan sistem vaskular. Reaksi oksidatif yang disebabkan oleh bahan fiksatif formalin pada jaringan menyebabkan afinitas jaringan embrio terhadap pewarnaan berkurang. ${ }^{7} \mathrm{Hal}$ ini menyebabkan warna $\mathrm{HE}$ pada embrio yang difiksasi menggunakan formalin akan lebih pudar sehingga batas antara jaringan vaskuler dan lingkungan sekitar tidak sejelas pada bahan fiksatif larutan Carnoy.

\section{Kesimpulan}

Berdasarkan hasil perbandingan fiksasi menggunakan larutan formalin dan fiksasi menggunakan larutan Carnoy pada embrio ayam usia 48 jam yang dicat menggunakan hematoxylin-eosin, maka disimpulkan bahwa:

1. Fiksasi larutan formalin dan Carnoy memiliki hasil yang cukup baik dan tidak berbeda signifikan dalam pengecatan hematoxylin-eosin pada neural tube embrio ayam usia 48 jam.

2. Fiksasi larutan formalin memiliki hasil yang lebih baik dan berbeda secara signifikan dibandingkan dengan fiksasi larutan Carnoy dalam pengecatan hematoxylin-eosin pada somit embrio ayam usia 48 jam.

3. Fiksasi larutan Carnoy memiliki hasil yang lebih baik dan berbeda secara signifikan dibandingkan dengan fiksasi larutan formalin dalam pengecatan hematoxylineosin pada vaskular embrio ayam usia 48 jam.

\section{Saran}

1. Penelitian serupa perlu menggunakan mesin penetas telur dengan kapasitas lebih besar dengan tujuan mengurangi kemungkinan error yang disebabkan oleh waktu proses fiksasi dan pewarnaan yang tidak seragam.

2. Diperlukan pembuatan standar kriteria dalam evaluasi kualitas penampakan embrio ayam, sehingga dapat memudahkan peneliti lain dalam evaluasi. 


\section{Daftar Pustaka}

1. Guus van der Bie. Early Development from a Phenomenological Point of View. Amsterdam: Louis Bolk Instituut. 2001.

2. Drake VJ, Koprowski SL, Lough JW, Smith SM. Gastrulating Chick Embryo as a Model for Evaluating Teratogenicity: A Comparison of Three Approaches. Birth Defects Research (PartA). Clinical and Molecular Teratology. 2006; 76:66-71.

3. Jusuf AA. Histoteknik Dasar. Tesis. Jakarta: Fakultas Kedokteran Universitas Indonesia. 2009.

4. Landis JR and Koch GG. The Measurement of Observer Agreement for Categorical Data. Biometrics. 1977; 33:159-74.
5. Talukder SI. Histopathology Techniques: Tissue Processing and Staining. (Online). 2007.http://www.talukderbd.com/lectures/ti ssue processing note.pdf.

6. Sumida SS. Biology 340, Comparative Embryology, Laboratory Exercise 3. (Online). 2008. http://www. stuartsumida. com/ BIOL340/340Lab3A.pdf.

7. Meyer $W$ and Hornickel IN. Tissue Fixation-The Most Underestimated Methodical Feature of Immunohistochemistry. Méndez-Vilas and Díaz J (Editors). Microscopy: Science, Technology, Applications and Education. 2010.

$\mathrm{P}$ 953-959. 